\title{
RESEARCH PAPER \\ The effects of the essential oil and hydrolate of canelo (Drimys winteri) on adults of Aegorhinus superciliosus in the laboratory
}

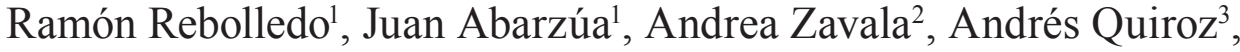 \\ Marysol Alvear ${ }^{3}$, and Alfonso Aguilera ${ }^{1}$ \\ ${ }^{1}$ Facultad de Ciencias Agropecuarias y Forestales. Universidad de La Frontera. Casilla 54-D. Temuco, Chile. \\ ${ }^{2}$ Facultad de Agronomía e Ingeniería Forestal, Pontificia Universidad Católica de Chile. Vicuña Mackenna \\ 4860, Macul. Santiago, Chile. \\ ${ }^{3}$ Facultad de Ingeniería, Ciencias y Administración. Universidad de La Frontera. Casilla 54-D. Temuco, \\ Chile.
}

\begin{abstract}
R. Rebolledo, J. Abarzúa, A. Zavala, A. Quiroz, M. Alvear, and A. Aguilera. 2012. The effects of the essential oil and hydrolate of canelo (Drimys winteri) on adults of Aegorhinus superciliosus in the laboratory. Cien. Inv. Agr. 39(3): 481-488. Drimys winteri (Magnoliids: Winteraceae), a native Chilean species, has potential for use as a botanical insecticide. This species contains chemicals with biological activity, such as isoprenoids and polyphenols. In this study, the effects of the essential oil and hydrolate of D. winteri on adults of Aegorhinus superciliosus were determined in the laboratory. This species is one of the most important pests associated with the cultivation of blueberries in Chile. The insecticidal effect of both distillates was determined for five concentrations of the essential oil and hydrolate of $D$. winteri, with ten replicates, in a completely random bioassay. The effects of these preparations on the egglaying, hatching and feeding activity of $A$. superciliosus were also evaluated. The essential oil produced $100 \%$ mortality at the highest concentration $(40 \% \mathrm{v} / \mathrm{v})$, whereas the greatest effect of the hydrolate was $12 \%$ at $100 \% \mathrm{v} / \mathrm{v}$. Ovicidal and anti-feeding effects were found for both distillates. In addition, a preliminary analysis was performed with gas chromatography coupled with mass spectrometry. This analysis detected the presence of polyphenolic secondary metabolites.
\end{abstract}

Key words: Essential oil, hydrolate, secondary metabolites.

\section{Introduction}

The effects of insecticides on insect physiology are based on a complex series of physical-chemical reactions that affect a particular species (Romanyk

Received: April 25 2011. Accepted: June 20, 2012.

Corresponding author: ramonr@ufro.cl and Cadahía, 2002). Due to their ease of use and availability in the market, synthetic insecticides have been the principal tool used by farmers to control pests. Their indiscriminate use has resulted in adverse environmental effects, including the appearance of resistance to these chemical agents and the destruction of natural control mechanisms, in addition to their high toxicity to humans (Silva et al., 2006; Devine et al., 2008; López et al., 2008; 
Siriwong et al., 2009). As a result, the search for alternative and/or complementary pest control methods has increased in recent years. One alternative is the use of plant species that have developed defense mechanisms through their interaction with herbivorous insects as a result of coevolution over thousands of years (Wink, 2003). Certain plants synthesize a wide range of chemicals called secondary metabolites (Yazaki, 2006; Hartmann, 2007, Howe and Jander, 2008), many of which may provide new natural biocides (Deidre et al., 2005). Furthermore, these natural compounds have lower toxicity and environmental impact (Harborne, 2001).

Drimys winteri, or "canelo", a Chilean native tree, is distributed between the Río Limari in the north $\left(30^{\circ} \mathrm{S}\right)$ and Cabo de Hornos in the south $\left(56^{\circ} \mathrm{S}\right)$ (Hoffmann et al., 1992).

The presence of biologically active compounds has been described in the leaves, stems and bark of this tree species. These compounds primarily include secondary isoprenoids (e.g., polygodial, drimenol and isodrimenol) and polyphenoids (Christine et al., 1982; Malherios et al., 2001; Muñoz et al., 2004; Muñoz et al., 2007; Limberger et al., 2007, Zapata et al., 2009). When ingested by certain insects, polygodial inhibits their capacity to feed, either temporarily or permanently, depending on the concentration (Muñoz et al., 2007, Zapata et al., 2009).

Recently, Monsálvez et al. (2010) reported a number of compounds in the essential oil obtained from canelo that displayed fungicidal activity on the fungus Gaeumannomyces graminis (Sacc.) Arx $\&$ D.L. Olivier. The growth of fungi was $50 \%$ inhibited by doses of 932 and $30.37 \mathrm{mg} \mathrm{L}^{-1}$ of hydrolate and essential oil, respectively.

The objective of this study was to evaluate the use of the essential oil and hydrolate of $D$. winteri as agents for the control of $A$. superciliosus (Guérin) (Curculionidae), the principal pest of blueberries. The study determined the insecticidal, ovicidal and antifeeding effects of these preparations. This curculionid is the principal pest associated with the cultivation of small fruits. Small fruit cultivation has grown exponentially in south central Chile over the past two decades, primarily for off-season exports to the northern hemisphere. The permanent establishment of these fruit plantations has created new agroecoystems offering favorable conditions for such native insect species as A. superciliosus. Because they feed on the roots, the larvae of this pest can cause the death of large numbers of plants in a plantation, and the adults cause severe defoliation (Guerrero and Aguilera, 1989; Aguilera 1994, 1995; Parra et al., 2009).

\section{Materials and methods}

The distillates were obtained from leaves and twigs of $D$. winteri collected in mid-October 2008 on a farm located at $38^{\circ} 58^{\prime} \mathrm{S}, 72^{\circ} 48^{\prime} \mathrm{W}$, near Freire, in the central plain of the Araucanía Region. The age of the trees was approximately 10 years, and their height was $6 \mathrm{~m}$. Beginning in November 2008, 500 adult specimens of $A$. superciliosus were collected on a commercial blueberry farm near Freire, Araucanía Region ( $38^{\circ} 57^{\prime} \mathrm{S}, 72^{\circ} 35^{\prime} \mathrm{W}$ ). They were kept at $5^{\circ} \mathrm{C}$ until the beginning of the bioassays. The insects were fed on leaves of Rubus ulmifolius Schott (Bramble).

The study was conducted from October 2008 through March 2009 in the Entomology Laboratory of the Facultad de Ciencias Agropecuarias y Forestales of Universidad de La Frontera. The essential oil and hydrolate were obtained by steam distillation in a $90 \mathrm{~L}$ Chilean-made stainless steel alembic, Villarrica city, Chile.

Insect mortality and secondary and anti-feeding effects were evaluated through independent assays for each distillate. The analyses of both distillates included five treatments (concentrations) (Table 1).

The insects were fed on $10 \mathrm{~cm}$ twigs of Rubus ulmifolius sprayed with the treatments at the 
Table 1. Treatments with essential oil and hydrolate of Drimys winteri used to determine the effects of these preparations on Aegorhinus superciliosus.

\begin{tabular}{lcc}
\hline Treatments & Essential oil/ acetone & Hydrolate / distilled water \\
\hline T0 & Control with no application & Control with no application \\
T1 & $5 \%(\mathrm{v} / \mathrm{v})$ & $10 \%(\mathrm{v} / \mathrm{v})$ \\
$\mathrm{T} 2$ & $10 \%(\mathrm{v} / \mathrm{v})$ & $20 \%(\mathrm{v} / \mathrm{v})$ \\
$\mathrm{T} 3$ & $20 \%(\mathrm{v} / \mathrm{v})$ & $40 \%(\mathrm{v} / \mathrm{v})$ \\
$\mathrm{T} 4$ & $40 \%(\mathrm{v} / \mathrm{v})$ & $100 \%$ hydrolate \\
\hline
\end{tabular}

beginning of the assay (hour 0 ); new treated leaves were given to the insects at 48 and $96 \mathrm{~h}$. The application was performed with a manual applicator at a rate of $950 \mathrm{~L} \mathrm{ha}^{-1}$.

Insect mortality was determined after 24,48 , 76,96 and $120 \mathrm{~h}$ on experimental units of five specimens in a $1 \mathrm{~L}$ plastic container, with ten replicates per treatment.

The effects of the distillates on egg-laying were evaluated by recording the number of eggs laid in $90 \mathrm{~mm}$ Petri dishes and the percentage hatched after 30 days for each treatment. The dishes were lined with absorbent paper moistened with distilled water. The eggs were obtained from the insects subjected to the different tests. In all, 78 eggs were collected for each treatment, as well as 78 eggs for the control.

To determine the antifeeding effect, the surface area of ten leaves of Vaccinium corymbosum L. (Blueberry) cv. Legacy was measured after spraying with the experimental treatments (Table 1). A sprayed leaf was introduced into a container with an adult $A$. superciliosus that had been held without food for the previous $24 \mathrm{~h}$. The area consumed was measured after $48 \mathrm{~h}$. Ten replicate measurements were performed. The differences in leaf area were determined with Arc View 3.2 Software.

A completely random experimental design was used in the assays, with five treatment concentrations and ten replicates. The efficacy percentages for control of $A$. superciliosus were calculated with Abbott's formula every $24 \mathrm{~h}$ up to $120 \mathrm{~h}$ for the degree of efficacy and ovicidal effect (Abbott,
1925). The percentages were transformed to angular values with the formula $Y=\arcsin \sqrt{x}$. Adult mortality and ovicidal and antifeeding effects were determined. The data were analyzed with an analysis of variance (ANOVA) and a Tukey multiple range test at $5 \%$ probability using SPSS 11 statistics software. The temperature and relative humidity were recorded daily using a Veto maximum and minimum thermometer and a Sundo hair hygrometer.

A gas chromatography-mass spectrometry (GCMS) analysis was performed with a $100 \mathrm{ppm}$ solution of essential oil in hexane, $1 \mu \mathrm{L}$ of which was injected into a gas chromatograph (Focus GC; Thermo Electron Composition, Waltham, USA) coupled to a mass detector (Finnigan FOCUS DSQ). The equipment consists of a $30 \mathrm{~m}, 0.22$ $\mathrm{mm}$ DBP-1 capillary column using helium as the carrier gas at a $1.5 \mathrm{~mL} \mathrm{~min}^{-1}$ flow rate and a $70 \mathrm{eV}$ electron beam with injection at $250^{\circ}$.

The initial temperature of the oven was programmed at $40{ }^{\circ} \mathrm{C}$ and then increased by $5{ }^{\circ} \mathrm{C} \mathrm{min}^{-1}$ to 280 ${ }^{\circ} \mathrm{C}$. This temperature was maintained for $10 \mathrm{~min}$. The mass spectra for each signal obtained from the chromatograms by GC-MS were compared with the NIST (V 2.0) internal library supplied by the instrument. This comparison defined the possible compounds detected at a defined percentage of certainty.

\section{Results and discussion}

The results presented below represent the cumulative effect of the bioassays. In general, measurements were taken up to $120 \mathrm{~h}$ with the exception 
of the assay that evaluated both distillates as antifeeding products, in which measurements were taken up to $48 \mathrm{~h}$. After $72 \mathrm{~h}$, the essential oil showed a significant insecticidal effect on the adult $A$. superciliosus, with $100 \%$ mortality observed after $120 \mathrm{~h}$ at the 20 and $40 \% \mathrm{v} / \mathrm{v}$ concentrations (Table 1).

The results demonstrated a relationship between the concentration of the essential oil and its insecticidal activity. In terms of the criterion proposed by Silva et al. (2005), who defined as promising only those treatments with a mortality higher than $40 \%$, the most effective treatments were the essential oil at 20 and $40 \% \mathrm{v} / \mathrm{v}$ because they produced the highest percentages of mortality and efficacy from the first application (Table 2).

These results confirm previous information about the essential oil of $D$. winteri, which contains chemical compounds whose biological activity is recognized. Previous studies (Muñoz et al., 2004, 2007 and Zapata et al., 2009) have cited polygodial sesquiterpene as an antimicrobial product and as a feeding inhibitor in certain insects, affecting the palatability of the food source and acting at the level of the digestive enzymes, and finally forming insoluble complexes in the digestive tract (Zapata et al., 2009). In addition, certain polyphenolic compounds, including caffeic acid, ferulic acids, vanillin, quercetin and luteolin show insecticidal activity in insects of various orders in both the adult and larval phases, causing impeded movement and subsequent mortality (Regnault-Roger et al., 2004). In our study, the secondary metabolites and alcohols present in high concentrations in the essential oil may have caused the preparation to act as an insecticide at the higher concentrations evaluated. In this respect, Regnault-Roger (1997) indicates that the insecticidal effects of essential oils may commonly act through inhalation, ingestion or topical absorption. For this reason, certain authors relate the insecticidal action of essential oils to the development of new alternatives for ecological pest control (Murray, 2000, 2005; Ricci et al., 2006 and Jbilou et al., 2008).

The hydrolate of $D$. winteri had no effect on the mortality of A. superciliosus, with no statistically significant differences between treatments (Table 3). The significant differences in biological activity between the essential oil and the hydrolate suggest that the apolar components were responsible for the mortality produced by the essential oil. This oil also showed effects on egg-laying in A. superciliosus. The data in Table 4 indicate that that the treatment significantly reduced egg-laying and the percentage of hatching after $120 \mathrm{~h}$ and $30 \mathrm{~d}$, respectively. Although the cumulative number of eggs laid is directly related to mortality, the hatching percentage is independent of mortality and would be a more accurate measure of the residual effects after the consumption of shoots treated with the essential oil. These residual effects of consumption would reduce the probability of hatching. Rodriguez et al. (2003) state that reduced egg-laying results from the inhibition of reproduction, affecting copulation, oocyte development, the pre-laying period, and the development, number, size and hatching of the eggs. However, during the period of time from collection in the field to the beginning of the bioassays, the specimens were kept in conditions that

Table 2. Efficacy percentage of essential oil from Drimys winteri for the control of $A$. superciliosus (calculated according to Abbott, 1925).

\begin{tabular}{lccccc}
\hline & \multicolumn{5}{c}{ Hours after application } \\
\cline { 2 - 6 } Treatments & 24 & 48 & 72 & 96 & 120 \\
\hline T0 control & $0 \mathrm{~b}$ & $0 \mathrm{c}$ & $0 \mathrm{c}$ & $0 \mathrm{~d}$ & $0 \mathrm{~d}$ \\
T1 $5 \%(\mathrm{v} / \mathrm{v})$ & $4 \mathrm{~b}$ & $10 \mathrm{bc}$ & $18 \mathrm{~b}$ & $20 \mathrm{c}$ & $22 \mathrm{c}$ \\
T2 $10 \%(\mathrm{v} / \mathrm{v})$ & $14 \mathrm{ab}$ & $28 \mathrm{~b}$ & $36 \mathrm{~b}$ & $42 \mathrm{~b}$ & $54 \mathrm{~b}$ \\
T3 $20 \%(\mathrm{v} / \mathrm{v})$ & $16 \mathrm{ab}$ & $58 \mathrm{a}$ & $86 \mathrm{a}$ & $90 \mathrm{a}$ & $100 \mathrm{a}$ \\
T4 $40 \%(\mathrm{v} / \mathrm{v})$ & $22 \mathrm{a}$ & $78 \mathrm{a}$ & $94 \mathrm{a}$ & $100 \mathrm{a}$ & $100 \mathrm{a}$ \\
\hline
\end{tabular}

Different letters indicate significant differences at $\mathrm{P} \leq 0.05$, Tukey test. 
were suitable for mating; they were not separated by sex. This observation suggests that females that were already fertilized were collected in the field or that females may have been fertilized during the period prior to the start of the bioassays. In contrast, the treatments with hydrolate did not affect egg hatching (Table 3 ) or adult mortality. This result would indicate that the polar compounds in the essential oil are digested more easily than the nonpolar compounds in the hydrolate. Each type of compound might affect the normal development of the life cycle of $A$. superciliosus. No existing references address the use of plant hydrolate on crop pests. A hydrosoluble substance that is present in a larger proportion than the oil, that shows independent chemical properties and that contains a small fraction of essential oil and oligoelements is unknown. Urano et al. (2003) reported the larvicidal effect of the hydrolate from Lippia siroides Cham. (Verbenaceae) on Aedes aegypti Linn. (Diptera: Culicidae), describing the hydrolate as a product that could contribute to progress in new alternatives for ecological pest control. The effects of hydrolate on mosquito egg-laying may be explained by the low concentrations of secondary metabolites, which generally act in nanoconcentrations.

The essential oil applied on blueberry leaves showed no anti-feeding effect on $A$. superciliosus . However, adult mortality reached $78 \%$ in treatment T4 $48 \mathrm{~h}$ after the application of essential oil (Table 2). Soon-II et al. (2003) indicate that these substances are highly volatile and most likely cause irreversible damage to membranes in the respiratory

Table 3. Efficacy percentage of hydrolate from Drimys winteri for the control of Aegorhinus superciliosus (calculated according to Abbott, 1925).

\begin{tabular}{lccccc}
\hline & \multicolumn{5}{c}{ Hours after application } \\
\cline { 2 - 6 } Treatments & 24 & 48 & 72 & 96 & 120 \\
\hline T0 control & $0 \mathrm{a}$ & $0 \mathrm{a}$ & $0 \mathrm{a}$ & $0 \mathrm{a}$ & $0 \mathrm{a}$ \\
T1 $10 \%(\mathrm{v} / \mathrm{v})$ & $2 \mathrm{a}$ & $6 \mathrm{a}$ & $10 \mathrm{a}$ & $12 \mathrm{a}$ & $12.2 \mathrm{a}$ \\
T2 $20 \%(\mathrm{v} / \mathrm{v})$ & $0 \mathrm{a}$ & $0 \mathrm{a}$ & $6 \mathrm{a}$ & $8 \mathrm{a}$ & $10.2 \mathrm{a}$ \\
T3 $40 \%(\mathrm{v} / \mathrm{v})$ & $2 \mathrm{a}$ & $4 \mathrm{a}$ & $6 \mathrm{a}$ & $6 \mathrm{a}$ & $4.10 \mathrm{a}$ \\
T4 $100 \%$ Hyd. & $2 \mathrm{a}$ & $4 \mathrm{a}$ & $6 \mathrm{a}$ & $6 \mathrm{a}$ & $12.2 \mathrm{a}$ \\
\hline
\end{tabular}

Different letters indicate significant differences at $\mathrm{P} \leq 0.05$, Tukey test. and digestive systems of the insects, particularly if the insects are confined in a small container. This result would indicate that the essential oil produces mortality both through consumption in low quantities and through inhalation.

Rodriguez et al. (2003) state that feeding inhibitors derived from plants are secondary metabolites that prevent the insects from responding positively to olfactory stimuli and therefore affect their ability to find and recognize their host plant.

The hydrolate presented a significant anti-feeding effect (Table 4). This finding may be a result of the occurrence of polar secondary metabolites, such as polygodial and flavonoids, in this fraction. Although these compounds do not make the hydrolate an insecticidal product per se, they do provide anti-feeding qualities that affect the palatability of the food substrate for A. superciliosus. These results are consistent with those of Zapata et al. (2009) on S. littoralis. The effects on S. littoralis were attributed to the anti-feeding effects of the sesquiterpenes polygodial and drimenol contained in the bark of $D$. winteri.

Based on our results, the essential oil of $D$. winter $i$ shows promise due to its insecticidal action on adults of $A$. superciliosus. The hydrolate of $D$. winteri had no insecticidal effect. In the investigations of egg-laying and hatching during the bioassay, the high mortality of the adult specimens made it difficult to determine whether the essential oil showed ovicidal action. In this sense, the hydrolate may be a useful alternative because it produces anti-feeding effects.

Table 4. Aegorhinus superciliosus eggs laid after $120 \mathrm{~h}$ and larvae hatched after 30 days in the presence of different concentrations of essential oil from Drimys winteri.

\begin{tabular}{|c|c|c|c|}
\hline Treatments & $\begin{array}{c}\mathrm{N}^{\circ} \text { of eggs } \\
\text { laid }\end{array}$ & $\begin{array}{c}\mathrm{N}^{\circ} \text { of larvae } \\
\text { hatched }\end{array}$ & $\%$ Hatching \\
\hline T0 Control & $78 \mathrm{a}$ & $76 \mathrm{a}$ & 97 \\
\hline T1 $5 \%(\mathrm{v} / \mathrm{v})$ & $32 \mathrm{~b}$ & $17 \mathrm{~b}$ & 53 \\
\hline T2 $10 \%(\mathrm{v} / \mathrm{v})$ & $12 \mathrm{c}$ & $5 \mathrm{c}$ & 41 \\
\hline T3 $20 \%(\mathrm{v} / \mathrm{v})$ & $6 \mathrm{~cd}$ & $2 \mathrm{c}$ & 16 \\
\hline T4 $40 \%(\mathrm{v} / \mathrm{v})$ & $1 \mathrm{~d}$ & $0 \mathrm{c}$ & 0 \\
\hline
\end{tabular}

Different letters indicate significant differences at $\mathrm{P} \leq 0.05$, Tukey test. 
The essential oil of $D$. winter $i$ had no anti-feeding effect on A. superciliosus but did produce high mortality and efficacy. In contrast, the hydrolate showed an anti-feeding effect. A chromatographic analysis demonstrated the presence of polyphenols (pinocmebrin and quercetin) in the essential oil and of caffeic acid in the hydrolate.

\section{Acknowledgements}

The authors of the present work are grateful for the support of DIUFRO Project DI 10-101 and DI12-0026 of the Research and Development Directorate of Universidad de La Frontera, and of FONDECYT Project 1070270.

\title{
Resumen
}

\begin{abstract}
R. Rebolledo, J. Abarzúa, A. Zavala, A. Quiroz, M. Alvear y A. Aguilera. Efecto del aceite esencial e hidrolato de canelo (Drimys winteri), en adultos de Aegorhinus superciliosus, bajo condiciones de laboratorio. Cien. Inv. Agr. 39(3): 481-488. Drimys winteri (Magnoliales: Winteraceae) especie nativa de Chile, tiene potenciales para ser utilizada como un insecticida de origen botánico. Trabajos previos han mostrado que esta especie presenta compuestos químicos con actividad biológica, tales como isoprenoides y polifenoles. En el presente estudio se determinó el efecto, bajo condiciones de laboratorio, de dos productos de la destilación de $D$. winteri (aceite esencial e hidrolato), sobre adultos de Aegorhinus superciliosus, considerado una de las plagas más importantes asociadas a cultivos de frutales menores en Chile. Los bioensayos se desarrollaron en el Laboratorio de Entomología de la Facultad de Ciencias Agropecuarias y Forestales de la Universidad de La Frontera (Temuco, Chile). Se determinó el efecto insecticida de ambos destilados sobre los insectos, utilizando cinco tratamientos incluyendo un testigo, con diez repeticiones, asignando a cada tratamiento diferentes concentraciones de aceite esencial e hidrolato de $D$. winteri. También se evaluaron sus efectos sobre oviposición, eclosión y la actividad alimentaria sobre $A$. superciliosus. El diseño experimental de los bioensayos correspondió a un diseño completamente aleatorizado. Los resultados, mostraron que el aceite esencial alcanzó un porcentaje de mortalidad del 100\%, con la mayor concentración; mientras que el mayor efecto del hidrolato llegó a 12\%, sobre insectos adultos. Se detectaron efectos ovicidas y antialimentarios en ambos destilados. Complementariamente se realizó un análisis preeliminar por cromatografía de gases acoplada a espectrometría de masas, encontrándose metabolitos secundarios polifenólicos.
\end{abstract}

Palabras clave: Aceite esencial, Aegorhinus superciliosus, Drimys winteri, hidrolato, metabolitos secundarios.

\section{References}

Abbot, W. 1925. A method of computing the effectiveness of an insecticida. Journal of Economic Entomology 18:265-267

Aguilera, A. 1994. Insectos y ácaros en frambuesa en la IX Región. Investigación y Progreso Agropecuario, INIA Carillanca (Temuco, Chile) 12: 27. Aguilera, A. 1995. Control selectivo de plagas en fru- tales en la zona sur. Seminario de protección vegetal INIA Carillanca (Temuco, Chile) 45:141-188.

Christine, A., W. Wayne, and J. Harvey. 1982. Leaf flavonoid patterns in the Winteraceae. Phytochemistry 21:329-337.

Devine, G., D. Eza, E. Ogusuku, and M. Furlong. 2008. Uso de insecticidas. Contexto y consecuencias ecológicas. Rev. Peruana Med. Exp. Salud Pública 25:74-100. 
Deidre, S., Charleston, A., Rami, A., M. Dicke, and E. Louise 2005. Vet impact of botanical pesticides derived from Melia azedarach and Azadirachta indica on the biology of two parasitoid species of the diamondback moth. Insect Ecology Queenswood 0121, South Africa Biological Control 33:131-142.

Guerrero, J., and A. Aguilera. 1989. Plagas y enfermedades del arándano chileno (Vacciun corimbosum L.). Próxima Década (Santiago, Chile) 7(76):24-29.

Hartmann, T. 2007. From waste products to ecochemicals: Fifty years research of plant secondary metabolism. Universitat Braunschweig. (Braunschweig, Germany). p. 2831-2846.

Harborne, J. 2001. Twenty-five years of chemical ecology. Nat. Prod. Rep. 18:361-379.

Hoffmann, A., C. Farga., J. Lastra, and Veghazi. 1992. Plantas Medicinales de Uso Común en Chile. Fundación Claudio Gay. Santiago, Chile. 275 pp.

Howe, G., and G. Jander. 2008. Plant Immunity to Insect Herbivores. Annu. Rev. Plant Biol. 59:4166.

Jbilou, R., H. Amri, N. Bouayad, N. Ghailani, A. Ennabili, and F. Sayah. 2008. Insecticidal effects of extracts of seven plant species on larval development, $\alpha$-amylase activity and offspring production of Tribolium castaneum (Herbst) (Insecta: Coleoptera: Tenebrionidae) Bioresource Technology 99:959-964.

Limberger, R., M. Scopel, M. Sobral, and A. Henriques. 2007. Comparative analysis of volatiles from Drimys brasiliensis Miers and D. angustifolia Miers (Winteraceae) from Southern Brazil Biochemical Systematics and Ecology 35:130-137.

López, M., M. Jordán, and M. Pascual-Villalobos. 2008. Toxic compounds in essential oils of coriander, caraway and basil active against stored rice pests. Journal of Stored Products Research 44:273-278.

Malheiros, A., V. Cechinel, C. Schmitt, A. Santos, C. Scheidt, and R. Yunes. 2001. A sesquiterpene drimane with antinociceptive activity from Drimys winteri bark. Phytochemistry 57:103-107.

Monsálvez, M., N. Zapata, M. Vergara, M. Berti, M. Bittner, and V. Hernández. 2010. Antifungal ef- fects of n-hexane extract and essential oil Drimys winteri bark against Take-all disease. Industrial Crops and Products 31:239-244.

Muñoz, D., H. Vogel, and L. Razmili. 2004. Variación de compuestos químicos en hojas de poblaciones de Drimys spp. (Magnoliophyta: Winteraceae) en Chile. Rev. Chil. Hist. Nat. 77:43-50.

Muñoz, D., H. Vogel, R. Yunes, I. Razmilic, L. Bresciani, and A. Malheiros. 2007. Presence of polygodial and drimenol in Drimys populations from Chile. Biochemical Systematics and Ecology 35:434-438.

Murray, B. 2000. Plant essential oils for pest and disease management. Crop Protection 19:603-608.

Murray, B. 2005. Chapter Six. Tropical forests as sources of natural insecticides. Recent Advances in Phytochemistry 39:145-161.

Parra, L., A. Mutis, A. Aguilera, R. Rebolledo, and A. Quiróz 2009. Estado del conocimiento sobre el cabrito del frambueso (CF) Aegorhinus superciliosus (Guérin) (Coleoptera: Curculionbidae). Idesia 27:57-65.

Regnault-Roger, C. 1997. The potential of botanical essential oil insect pest control. Integrated Pest Management Review 2:25-34

Regnault-Roger, C. Ribodeaua, M., Hamraouia, A., I. Bareaua, P. Blancharda, M. Gil-Muñoz, and F. Barberanb. 2004. Polyphenolic compounds of Mediterranean Lamiaceae and investigation of orientational effects on Acanthoscelides obtectus (Say). Journal of Stored Products Research 40:395-408.

Ricci, M., S. Padín, J. Ringuelet, and A. Kahan. 2006. Utilización de Aceite Esencial de Lemongrass (Cymbopogon citratus Stapf) Como Repelente de Diuraphis noxia Kurdj. (Hemiptera: Aphididae) en Trigo. Agric. Téc. (Chile) 66:256-263.

Romanyk, N., and D. Cadahía. 2002. Plagas de Insectos en las Masas Forestales. Mundi-Prensa. Madrid, España. 336 pp.

Rodríguez, C., G. Silva, and J. Vendramin. 2003. Insecticidas de origen Vegetal. In: Silva, G., and R. Hepp (eds.). Bases para el manejo racional de insecticidas. Universidad de Concepción. Trama Impresores S.A. Chillán, Chile. p. 87-112.

Silva, G., I. Kiger, R. Hepp, and M. Tapia. 2005. Control de Sitophilus zeamais con polvos veg- 
etales de tres especies del género Chenopodium. Pesq. Agropec. Bras. 40:053-960.

Silva, G., J. Rodríguez, and J. Bernal. 2006. Resistencia de parasitoides y depredadores de plagas agrícolas a insecticidas. Agro-ciencia 22:37-48.

Siriwong, W., K. Thirakhupt, D. Sitticharoenchai, J. Rohitrattana, P. Thongkongowm, M. Borjan, and M. Robson. 2009. DDT and derivatives in indicator species of the aquatic food web of Rangsit agricultural area, Central Thailand. Ecological Indicators 9:878-882.

Soon-Il, K.; R. Jung-Yeon, K. Do-Hyoung, H. Lee, and H. Ahn. 2003. Insecticidal activities of aromatic plant extracts and essential oils against Sitophilus oryzae and Callosobruchus chinensis. Journal of Stored Products Research 39:293-303.
Urano, A., V. Maciel, A. Aragao, M. Machado, M. Braga, and E. Fontenele. 2003 Larvicidal activity of the essential oil from Lippia sidoides Cham. against Aedes aegypti Linn. Mem Inst Oswaldo Cruz (Rio de Janeiro) 98:569-571.

Wink, M. 2003. Evolution of secondary metabolites from an ecological and molecular phylogenetic perspective. Phytochemistry 64:3-19.

Yazaki, K. 2006. ABC transporters involved in the transport of plant secondary metabolites. FEBS Letters 580:1183-1191.

Zapata, N., F. Budia, E. Viñuela, and P. Medina. 2009. Antifeedant and growth inhibitory effects of extracts and drimanes of Drimys winteri stem bark against Spodoptera littoralis (Lep., Noctuidae). Industrial Crops and Products 30:119-125. 